\title{
Hubungan Masa Kerja dengan Keluhan Carpal Tunnel Syndrome pada Karyawan Pengguna Komputer di Bank BJB Cabang Subang
}

\author{
Kintan Nafasa, ${ }^{1}$ Yuniarti, ${ }^{2}$ Nurdjaman Nurimaba, ${ }^{3}$ Cice Tresnasari, ${ }^{4}$ \\ Caecielia Wagiono 5 \\ ${ }^{1}$ Program Studi Pendidikan Dokter Fakultas Kedokteran Universitas Islam Bandung \\ ${ }^{2}$ Bagian Anatomi Fakultas Kedokteran Universitas Islam Bandung \\ ${ }^{3}$ Bagian Neurologi Fakultas Kedokteran Universitas Islam Bandung \\ ${ }^{4}$ Bagian Fisiologi Fakultas Kedokteran Universitas Islam Bandung \\ ${ }^{5}$ Bagian Fisiologi Fakultas Kedokteran Universitas Islam Bandung
}

\begin{abstract}
Abstrak
Insidensi kejadian carpal tunnel syndrome (CTS) 3,8\% di dunia dan insidensi lebih tinggi pada individu yang pekerjaannya memerlukan fleksi atau ekstensi jari berulang dalam waktu yang lama seperti karyawan bank. Penelitian ini bertujuan menganalisis hubungan antara masa kerja dan keluhan CTS pada karyawan Bank BJB Cabang Subang yang bekerja menggunakan komputer. Penelitian ini pendekatan potong lintang dan instrumen pengumpulan data menggunakan Boston Carpal Tunnel Syndrome Questionnaire. Sampel adalah 54 karyawan Bank BJB Cabang Subang yang menggunakan komputer. Kriteria inklusi adalah perempuan dan laki-laki berusia $\geq 24$ tahun, menggunakan komputer pada saat bekerja, serta tidak memiliki riwayat diabetes melitus dan artritis reumatoid. Kriteria eksklusi, yaitu memiliki masa kerja kurang dari satu tahun, memiliki riwayat trauma tangan atau pergelangan tangan, sedang hamil, atau telah menopause. Analisis data dilakukan dengan Uji Eksak Fisher dan didapatkan $\mathrm{p}=0,000(<0,05)$ terdapat hubungan signifikan masa kerja dengan keluhan CTS pada karyawan Bank BJB Cabang Subang yang menggunakan komputer. Kelompok yang memiliki masa kerja $\geq 4$ tahun memiliki proporsi CTS lebih besar dibanding dengan kelompok yang memiliki masa kerja <4 tahun. Semakin lama masa kerja maka semakin tinggi risiko CTS karena terjadi gerakan berulang pada jari tangan secara terus-menerus dalam jangka waktu yang lama sehingga dapat menyebabkan kompresi pada jaringan sekitar carpal tunnel.
\end{abstract}

Kata kunci: Carpal tunnel syndrome, karyawan pengguna komputer, masa kerja

\section{Relationship between Work Period to Complaints of Carpal Tunnel Syndrome on Employees at Bank BJB Subang Working Using Computer}

\begin{abstract}
Incidence rates of carpal tunnel syndrome (CTS) $3.8 \%$ in the world. CTS incidence rates are higher in individuals whose jobs require long-term flexion or extension of fingers, such as bank employees. This study aimed to analyze the relationship between work period to complaints of CTS on employees at Bank BJB Subang working using computer. This research cross sectional approach and data collection using Boston Carpal Tunnel Syndrome Questionnaire. The target population of this research was all employees of Bank BJB Subang, while its accessible population was all employees of Bank BJB Subang that use computer. Samples were 54 employees at Bank BJB Subang is working on computer. Inclusion criteria was women and men aged $\geq 24$ years who used the computer at work and had no history of diabetes mellitus and rheumatoid arthritis, while the exclusion criteria are those who has work period less than a year, history of hand or wrist injury, pregnant or menopause. Technique of data processing and data analysis conducted by statistical test Fisher's exact test meaningful results is p-value $=0.000(<0.05)$ thus there was a significant relationship between work period of complaints CTS on Employees at Bank BJB Subang Working Using Computer, which in the group who had working period more than four years had a higher proportion of CTS than the group with the working period less than four years. Risk of CTS will be higher for those who is working for a long period, because of repetitive movements of the fingers continuously for long periods of time can cause compression on the tissue around the carpal tunnel.
\end{abstract}

Key words: Carpal tunnel syndrome, employees using computer, work period 


\section{Pendahuluan}

Carpal tunnel syndrome (CTS) didefinisikan sebagai kompresi nervus medianus pada pergelangan tangan dan termasuk sindrom kompresif yang paling sering terjadi. ${ }^{1}$ Insidensi cukup tinggi $\pm 3,8 \%$ populasi dunia. ${ }^{2}$ Pada tahun 2001, CTS menempati posisi keenam dari semua penyakit akibat kerja di Uni Eropa dan sejak tahun 2003 CTS termasuk ke dalam daftar penyakit akibat kerja di Uni Eropa. ${ }^{3}$

Hasil penelitian Roquelaure dkk. ${ }^{4}$ menunjukkan bahwa tingkat kejadian CTS lebih tinggi pada individu yang bekerja dibanding dengan individu tidak bekerja. Insidensi CTS lebih tinggi pada pekerja menggunakan mesin yang bergetar dan pada pekerja kantor yang memerlukan fleksi atau ekstensi jari berulang dalam waktu yang lama, terutama juru ketik dan petugas pemasukan data. ${ }^{5}$ Penggunaan perangkat elektronik secara statis dalam waktu yang lama terutama komputer dapat memengaruhi muskuloskeletal pekerja kantor akibat posisi tangan yang salah pada saat menggunakan mouse atau keyboard dan pekerjaan yang berulang (repetitive work). ${ }^{6}$ Penggunaan keyboard lebih dari empat jam per hari merupakan faktor risiko keluhan nyeri pada ekstremitas atas. Bagian tubuh yang paling sering mengalami keluhan adalah bahu, pergelangan tangan, serta tangan. ${ }^{7}$ South Texas Veterans Health Care System di San Antonio, Texas, Amerika Serikat mengemukakan bahwa CTS itu merupakan penyakit yang berhubungan dengan komputer pada sebagian besar populasi di Amerika. ${ }^{5}$ Penelitian pada operator komputer perempuan yang melaksanakan pekerjaan pemasukan data selama enam jam sehari didapatkan prevalensi CTS yang tinggi. ${ }^{5}$ Sebuah survei terhadap para karyawan yang sering menggunakan komputer, 29,6\% mengeluhkan paraestesia pada tangan dan 10,5\% memenuhi kriteria klinis CTS. Hasil penelitian menunjukkan bahwa penggunaan komputer dengan masa kerja lebih dari empat tahun dan durasi kerja menggunakan komputer lebih dari delapan jam per hari ditemukan sebagai faktor risiko CTS. Karyawan di bidang administrasi 2,4 kali berisiko mengalami CTS bila dibanding dengan pekerja komputer lainnya. Pergelangan tangan dalam posisi fleksi atau ekstensi dalam waktu yang lama juga ditemukan sebagai faktor risiko CTS. ${ }^{5}$ Penelitian sebelumnya oleh Saerang dkk. ${ }^{8}$ pada karyawan bank di Kota Bitung yang menggunakan komputer menunjukkan prevalensi CTS sebesar $28 \%$.

Pada penelitian pendahuluan yang dilakukan pada 11 orang karyawan Bank BJB Cabang Subang, yaitu bagian teller, administrasi, dan customer service yang dilakukan pada tanggal 18 Desember 2017 didapatkan delapan dari 11 orang mengalami keluhan CTS dengan persentase nyeri $(75 \%)$, kesemutan $(19 \%)$, dan mati rasa (6\%), serta memiliki masa kerja lebih dari empat tahun.

Penelitian bertujuan mengetahui hubungan antara masa kerja dan keluhan CTS pada karyawan Bank BJB Cabang Subang yang merupakan Bank Usaha Milik Daerah Provinsi Jawa Barat dan Banten.

\section{Metode}

Penelitian ini termasuk ke dalam penelitian analitik observasional. Berdasar atas waktunya termasuk dalam penelitian potong lintang karena pengukuran serta pengamatan terhadap variabel penelitian dilakukan pada waktu tertentu. Tempat pelaksanaan penelitian di Bank BJB Cabang Subang Jalan Jend. A. Yani No. 2 Subang, Jawa Barat. Penelitian dilaksanakan pada bulan April 2018.

Populasi target pada penelitian ini adalah seluruh karyawan bank di Kota Subang yang mempergunakan komputer. Populasi terjangkau seluruh karyawan Bank BJB Cabang Subang yang mempergunakan komputer, pemilihan subjek dengan menggunakan metode simple random sampling.

Jumlah subjek minimum yang terlibat dihitung menggunakan formula uji hipotesis beda dua proporsi dan didapatkan sampel sebanyak 54 orang. Kriteria inklusi dalam penelitian ini, yaitu perempuan dan lakilaki berusia $\geq 24$ tahun dan menggunakan komputer pada saat bekerja serta tidak memiliki riwayat diabetes melitus dan juga artritis reumatoid, sedangkan kriteria eksklusi memiliki masa kerja kurang dari satu tahun, mempunyai riwayat trauma tangan atau pergelangan tangan, sedang hamil, atau telah menopause.

Instrumen yang dipergunakan untuk memperoleh informasi dari responden, yaitu Boston Carpal Tunnel Syndrome Questionnare atau BCTS yang telah diuji validitas dan reabilitasnya. BCTS merupakan ukuran hasil berbasis pasien yang telah dikembangkan khusus untuk pasien CTS. Kuesioner ini memiliki dua skala yang berbeda, skala keparahan gejala yang memiliki 11 pertanyaan dan skala status fungsional yang berisi delapan pertanyaan, namun yang dipergunakan dalam penelitian ini hanyalah skala keparahan gejala. Setiap pertanyaan mempunyai 5 (lima) jawaban bernomor satu hingga lima yang disusun dalam jumlah yang meningkat sesuai dengan urutan keparahan gejala. Skor keparahan gejala dijumlahkan dan dikategorikan ke dalam lima grup: tidak ada gejala (skor total: 11); ringan (skor total: 12-22); sedang (skor total: 23-33); berat (total skor: 34-44); dan sangat parah (skor total: 45-55). Seluruh kuesioner yang sudah dikumpulkan, kemudian dilakukan beberapa tahap pengolahan data, yaitu editing, coding, data entry, dan cleaning.

Analisis data dilaksanakan menggunakan analisis univariat serta bivariat. Analisis univariat dilakukan terhadap tiap-tiap variabel yang dipergunakan dalam penelitian dengan mengacu pada data yang diperoleh. Analisis bivariat dilakukan dengan mengorelasikan variabel bebas dengan variabel terikat. Uji statistik yang digunakan adalah Uji Eksak Fisher.

Penelitian ini telah mendapat izin dari Komite Etik Penelitian Fakultas Kedokteran Universitas Islam Bandung Nomor: 201/Komite Etik.FK/III/2018

\section{Hasil}

Karakteristik subjek merupakan karyawan Bank BJB Cabang Kota Subang yang mempergunakan komputer sebanyak 54 orang (Tabel 1).

Tabel 2 menunjukkan bahwa nilai p (Uji Eksak Fisher) signifikan kurang dari alpha yang ditentukan $(0,05)$ sehingga dapat disimpulkan terdapat hubungan bermakna lama kerja dengan keluhan CTS. Kelompok yang mempunyai lama kerja lebih atau sama dengan empat tahun mempunyai proporsi CTS lebih besar dibanding dengan kelompok yang mempunyai lama kerja kurang dari empat tahun. 
Tabel 1 Karakteristik Subjek Penelitian

\begin{tabular}{|c|c|c|c|}
\hline \multicolumn{2}{|c|}{ Karakteristik Subjek } & \multirow{2}{*}{$\begin{array}{c}\text { Frekuensi } \\
28\end{array}$} & \multirow{2}{*}{$\begin{array}{c}\text { Persentase } \\
52\end{array}$} \\
\hline Jenis kelamin & Laki-laki & & \\
\hline & Perempuan & 26 & 48 \\
\hline \multirow[t]{2}{*}{ Usia (tahun) } & $<30$ & 39 & 72 \\
\hline & $\geq 30$ & 15 & 28 \\
\hline \multirow[t]{4}{*}{ IMT } & $<18,50$ (underweight) & 2 & 4 \\
\hline & $18,5^{-24,99}$ (normal) & 45 & 83 \\
\hline & $\geq 25$, oo (overweight) & 7 & 13 \\
\hline & $\geq 30,00$ (obese) & 0 & o \\
\hline \multirow[t]{2}{*}{ Masa kerja (tahun) } & $<4$ & 20 & 37 \\
\hline & $\geq 4$ & 34 & 63 \\
\hline \multirow[t]{2}{*}{ CTS } & Positif & 38 & 70 \\
\hline & Negatif & 16 & 30 \\
\hline \multirow[t]{4}{*}{ Keparahan CTS } & Asimtomatik & 16 & 30 \\
\hline & Ringan & 28 & 52 \\
\hline & Sedang & 8 & 15 \\
\hline & Parah & 2 & 3 \\
\hline \multirow[t]{5}{*}{ Gejala CTS } & Nyeri & 29 & 54 \\
\hline & Kesemutan & 24 & 44 \\
\hline & Mati rasa & 14 & 26 \\
\hline & Nokturnal & 20 & 37 \\
\hline & Kelemahan genggaman & 12 & 22 \\
\hline
\end{tabular}

Tabel 2 Hubungan Masa Kerja dengan Keluhan CTS

\begin{tabular}{cccccccc}
\hline \multirow{2}{*}{ Masa Kerja } & \multicolumn{3}{c}{ CTS } & \multirow{2}{*}{ PR } & IK 95\% & $\begin{array}{c}\text { Nilai } \\
\text { p }\end{array}$ \\
\cline { 2 - 5 } & $\begin{array}{c}\text { Negatif } \\
\mathbf{n = 1 6}\end{array}$ & $\begin{array}{c}\text { Positif } \\
\mathbf{n = 3 8}\end{array}$ & $\begin{array}{c}\text { Total } \\
\mathbf{n = 5 4}\end{array}$ & & & \\
\hline 4 tahun & 13 & 7 & 20 & 2,61 & 1,42 & 4,78 & 0,00 \\
4 tahun & 3 & 31 & 34 & & & \\
\hline
\end{tabular}

\section{Pembahasan}

Hasil penelitian ini sesuai dengan hasil penelitian Ali dan Sathiyasekaran ${ }^{5}$ yang menyatakan bahwa pengguna komputer $\geq 4$ tahun memiliki risiko yang lebih besar mengalami CTS bila dibanding dengan penggunaan komputer $<4$ tahun. Penelitian Abdellah dkk. ${ }^{9}$ pada pekerja kantor di Mesir diketahui bahwa subjek dengan masa kerja 5-10 tahun mempunyai risiko CTS lebih besar dibanding dengan masa kerja $<5$ tahun. Hasil penelitian ini juga sesuai dengan penelitian Juniari dan TriWahyudi. ${ }^{10}$ pada pengguna komputer di sebuah universitas yang menunjukkan bahwa subjek yang memiliki masa kerja $>4$ tahun terdapat 60,6\% yang mengalami CTS bila dibanding dengan subjek masa kerja $<4$ tahun, yaitu 18,3\% yang mengalami CTS. Masa kerja menunjukkan lamanya paparan di tempat kerja. Semakin lama masa kerja maka akan semakin tinggi pula risiko terjadi penyakit akibat kerja seperti CTS. ${ }^{11}$ Penelitian oleh Bugajska dkk. ${ }^{12}$ mengemukakan bahwa insidens CTS cenderung meningkat seiring pertambahan jumlah tahun kerja. Burt dkk. ${ }^{13}$ mengemukakan bahwa tempat kerja dan faktor risiko individu berkontribusi pada risiko CTS. Risiko CTS itu meningkat dengan peningkatan jumlah waktu yang dipergunakan dalam melakukan gerakan fleksi pergelangan tangan yang berulang. Penelitian Werner dkk. ${ }^{14}$ terhadap karyawan pengguna komputer mengemukakan bahwa gejala CTS muncul setelah 17 bulan, tetapi secara signifikan lebih tinggi setelah 70 bulan. Penelitian ini juga memperlihatkan efek yang signifikan tahun dan jam per hari dengan penggunaan komputer bahwa semakin lama memakai komputer maka semakin berisiko mengalami CTS. 
Fung dkk. ${ }^{15}$ mengidentifikasi semakin sering fleksi atau ekstensi pergelangan tangan yang berkelanjutan dapat meningkatkan risiko CTS. Pengulangan gerakan tangan dapat menimbulkan risiko 2x lipat terjadi CTS. Hal ini terjadi karena semakin lama masa kerja akan terjadi gerakan berulang pada jari tangan secara terusmenerus dalam jangka waktu yang lama sehingga dapat menyebabkan kompresi pada jaringan sekitar carpal tunnel. Selain itu, dengan terdapat peningkatan masa kerja yang dominan mempergunakan tangan menunjukkan pekerjaan berulang pada tangan dalam waktu lama sehingga menyebabkan risiko lebih tinggi terjadi CTS.,5,

Berdasar atas keparahan gejala CTS hasil penelitian memperlihatkan $52 \%$ subjek mengalami CTS ringan, $15 \%$ mengalami CTS sedang, dan 4\% mengalami CTS parah. Hasil penelitian ini sesuai dengan penelitian Mody dkk. ${ }^{17}$ pada pasien CTS di India yang menunjukkan keparahan gejala CTS yang paling banyak CTS ringan. Penelitian Mat Zain dkk. ${ }^{18}$ pada karyawan yang menggunakan komputer ditemukan 73,3\% subjek mengalami CTS ringan diikuti dengan $15 \%$ yang mengalami CTS sedang. Terdapat $1,7 \%$ yang mengalami CTS parah dan tidak ditemukan subjek yang mengalami CTS sangat parah. Peningkatan CTS diakibatkan oleh desain peralatan kerja (meja dan kursi), teknik bekerja yang salah (postur janggal), pekerjaan yang berulang pada tangan dengan durasi kerja yang lama, serta penyakit sistemik (artiris dan diabetes) yang dapat memperparah gejala CTS. ${ }^{19} \mathrm{Hal}$ ini dapat terjadi karena kompresi nervus medianus yang apabila terus berlanjut akan terjadi fibrosis epineural yang merusak serabut saraf. Lama-kelamaan saraf itu menjadi atrofi dan digantikan oleh jaringan ikat yang akan mengakibatkan fungsi nervus medianus terganggu secara menyeluruh. ${ }^{20}$

Gejala CTS berdasar hasil penelitian menunjukkan $54 \%$ subjek mengalami keluhan nyeri, 44\% keluhan kesemutan, 37\% keluhan nokturnal, 26\% keluhan mati rasa, dan $22 \%$ dengan keluhan kelemahan genggaman. Hasil penelitian ini sesuai dengan penelitian Saerang dkk. ${ }^{8}$ pada karyawan di Kota Bitung bahwa berdasar atas keluhan yang dirasakan oleh karyawan maka nyeri merupakan keluhan yang paling banyak dialami sekitar $75 \%$. Menurut Ibrahim dkk. ${ }^{21}$ gejala utama CTS meliputi nyeri, kesemutan, mati rasa pada distribusi distal nervus medianus (ibu jari, telunjuk, jari tengah, dan jari manis), dan penurunan kekuatan genggaman pada tangan. Gejala cenderung memburuk di malam hari dan tangan kaku pada siang hari terutama pada aktivitas yang membutuhkan fleksi pergelangan tangan. Menurut penelitian Subhalaksmi dan Sujatha. ${ }^{22}$ pada pengguna komputer di sebuah kantor, gejala CTS yang paling umum adalah nyeri tangan atau pergelangan tangan $89,47 \%$; mati rasa $26,31 \%$; kelemahan tangan 15,78\%; eksaserbasi nokturnal 10,52\%; kesemutan 10,52\%; dan juga kesulitan dalam memegang benda sebesar 7,89\%. Pekerjaan khas pasien CTS termasuk menggunakan komputer untuk jangka waktu lama atau menggunakan peralatan yang memiliki getaran seperti pekerja konstruksi dan pekerjaan lain yang sering membutuhkan gerakan tangan berulang. ${ }^{23}$

\section{Simpulan}

Simpulan penelitian ini terdapat hubungan masa kerja dengan keluhan CTS. Kelompok yang memiliki masa kerja $\geq 4$ tahun mempunyai proporsi CTS lebih besar dibanding dengan kelompok yang mempunyai masa kerja $<4$ tahun.

\section{Ucapan Terima Kasih}

Terima kasih kepada staf divisi Sumber Daya Manusia (SDM) Bank BJB Cabang Subang serta para karyawan yang telah bersedia menjadi objek penelitian penulis serta pihak-pihak yang turut membantu penulis dalam penyelesaian artikel ini.

\section{Daftar Pustaka}

1. Chammas M, Boretto J, Burmann LM, Ramos RM, Neto FCS, Silva JB. Carpal tunnel syndrome - Part 1 (anatomy, physiology, etiology and diagnosis). Rev Bras Ortop. 2014;49(5):429-65.

2. Atroshi I, Gummesson C, Johnsson R, Ornstein E, Ranstan J, Rosén I. Prevalence of carpal tunnel syndrome in a general population. JAMA. 2009;282(2):153-8.

3. Giersiepen K, Spallek M. Carpal tunnel syndrome as an occupational disease. Dtsch Arztebl Int. 2011 Apr;108(14):238-42.

4. Roquelaure Y, Pelier C, Nicolas G, Descatha A, Leclerc A, Raimbeau G, dkk. Work increases the incidence of carpal tunnel syndrome in the general population. Muscle Nerve. 2008 Apr;37(4):477-82.

5. Ali KM, Sathiyasekaran BWC. Computer professionals and carpal tunnel syndrome (CTS). JOSE. 2006;12(3):319-25.

6. Lee J, Koo JW. Occupational diseases among office workers and prevention strategies. JESK. 2015;34(2):125-34.

7. Palmer KT, Cooper C, Walker-Bone K, Syddall H, Coggon D. Use of keyboards and symptoms in the neck and arm: evidence from a national survey. Occup Med (Lond). 2001 Sep;51(6):392-5.

8. Saerang D, Kembuan M, Karema W. Insiden carpal tunnel syndrome berdasar atas anamnesis pada karyawan Kota Bitung Sulawesi Utara. J e-Clinic (eCl). 2015 Jan-Apr;3(1):579-84.

9. Abdellah RF, Morsy KM, Elshaboury I. Prevalance and risk factor of carpal tunnel syndrome among workers in the construction study. Egypt J Occupat Med. 2016;40(1):1-13.

10. Juniari GAR, TriWahyudi A. Hubungan antara masa kerja terhadap keluhan carpal tunnel syndrome (CTS) pada pegawai perempuan di kampus universitas dhyana pura yang bekerja menggunakan komputer. J Virgin. 2015 Jul;1(2):162-8.

11. Tarwaka, Solichul HA, Sudiajeng L. Konsep dasar ergonomi. Dalam: Annis JF, Astrand PO, Corlett EN, Geinady AM, Grandjean E, penyunting. Ergonomi untuk keselamatan, kesehatan kerja dan produktivitas, Edisi ke-1. Surakarta: UNIBA; 2004. hlm. 3-14. 
12. Bugajska J, Jedryka-Góral A, Sudoł-Szopińska I, Tomczykiewicz K. Carpal tunnel syndrome in occupational medicine practice. JOSE. 2007;13(1): 29-38.

13. Burt S, Deddens JS, Crombie K, Jin Y, Wurzelbacher S, Ramsey J. A prospective study of carpal tunnel syndrome: workplace and individual risk factors. Occup Environ Med. 2013;70(8):568-74.

14. Werner RA, Gell N, Franzblau A, Armstrong TJ. Prolonged median sensory latency as a predictor of future carpal tunnel syndrome. Muscle Nerve. 2011;24:1462-7. doi: 10.1002/mus.11

15. Fung BK, Chan KY, Lam LY, Cheung SY, Choy NK, Chu KW, dkk. Study of wrist posture, loading and repetitive motion as risk factor for developing carpal tunnel syndrome. Hand Surg. 2008;12(1):13-8.

16. Agustin CPM. Masa kerja, sikap kerja, dan kejadian sindrom karpal pada pembantik. KEMAS. 2012;7(2):170-6.

17. Mody GN, Anderson GA, Thomas BP, Pallapati SC, Santoshi JA, Antonisamy B. Carpal tunnel syndrome in indian patients: use of modified questionaires for assesment. J Hand Surg Eur. 2009;34(5):671-8.

18. Mat Zain NH, Jaafar A, Abdul Razak FH. Severity scoring of symptoms associated with carpal tunnel syndrome based on recall of computer game playing experience. J Theor Applied Information Technol. 2014 May 10;63(1):1-11.

19. Lisay EKR, Polii H, Doda V. Hubungan durasi kerja dengan keluhan carpal tunnel syndrome pada juru ketik di Kecamatan Malalayang Kota Manado. JKK. 2016 Desember;1(2):28-46.

20. Bahrudin M. Carpal tunnel syndrome: Malang. Saintika Medika. 2011 Feb;7(1):78-87.

21. Ibrahim I, Khan WS, Goddard N, Smitham P. Carpal tunnel syndrome: a review of the recent literature. Open Orthop J. 2012;6:69-76. doi: 10.2174/1874325001206010069.

22. Subhalakshmi S, Sujatha B. A study of carpal tunnel syndrome among regular computer users and effect of yogic exercises in them. IJSR. 2016 Sep;5(9):4-5.

23. Sevy JO, Dulebohn OS. Carpal tunnel syndrome. ETSU, Meharry, LMU: Stat Pearls; 2018:1-7. 